\title{
アゾ基を有するフタロン系顔料の研究
}

高木邦彦*・安藤浩人・*水野毅*** 高木浩一**・糸屋喜雄*

\section{Studies on Phthalone Pigments Bearing a \\ Group of an Azo Dye as a Substituent}

\author{
Kunihiko TAKagr*, Hirohito Ando*, \\ Takeshi Mizuno***, Koichi TaKagI ${ }^{* *}$ \\ and Yoshio IтонA*
}

\begin{abstract}
It is known that imidazole-phthalone pigments have very good fastness to heat, solvents and light.

As a part of studies on these pigments, a method for synthesis of compounds of formula (I) and (II), in which a group of an azo dye was a substituent, and their pigment properties were investigated. Their printed colors on paper were greenish yellow, yellow, reddish yellow, orange or brown shades. Their color strength and their fastness properties, in particular, the fastness to heat, solvents, acid and alkali, were generally up to those of commercial modern pigments. On the other hand, most of them had no good light fastness.
\end{abstract}

The azo group was an important factor influencing the shades of these pigments, their color strength and the fastness to light.

\section{要旨}

イミダゾール・フタロン顔料は，すでに良好な各種顔 料適性を有することが知られている1。これらのフタロ ン系顔料の研究の一環として, 黄色系アゾ基を置換基と して有する誘導体を種々合成し，それらの顔料適性を調

昭和 50.8.25 受理

* 大日本インキ化学工業 (株) 鹿島工場 茨城県鹿島郡神栖町大字東深芝 18

**大日本インキ化学工業 (株) 吹田工場 吹田市吉志部 196

*** 故人

* Dainippon Ink and Chemicals, Inc., Kashima Kashima-gun, Ibaragi-ken, Japan

** Dainippon Ink and Chemicals, Inc., Suita Suita-shi, Japan

$* * *+$

$8[3]$
ベた。今回合成した顔料は，一般式（I），および（II） で表わされる。

これらの顔料の色相は，アゾ基の影響が大きく，青味 黄色から登色まで広範囲にわたった。着色力は, 一般に 大きく, 耐熱性, 而溶剤性, 耐薬品性は, いずれもきわ<smiles>[R1]NN(C(C)=O)C(C)=O</smiles>

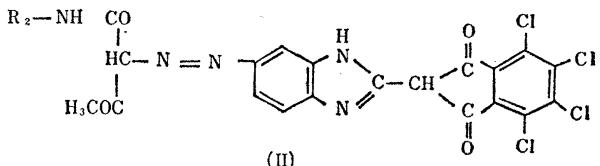

(II)

(I) 
めて良好であった。耐光性は，一部を除いて一般に良く なかった。

\section{1. 緒言}

フタロン系色素はその歷史も古く2), 特許を含め文 献の数はきわめて多い。顔料についても最近多くの特 許 ${ }^{3345)}$ があり, 実際にもいくつかの顔料が上市され，そ の良好な耐熱性と耐候性によりかなり使用されている。 しかし，これらはいずれもキナルジンの誘導体を使用し たものであり，耐溶剤性が十分ではないために使用範囲 が限定されている。一方，キナルジンの代わりに 2-メ チルベンッイミダゾール（III）抢よびその誘導体を使っ て合成したフタロン系顔料は，きわめて良好な耐溶剂性， 耐熱性, 耐薬品性, 耐光性を有することがすでに知られ ている1)。そこで本報告では，この 2-メチルベンッイミ ダゾール環に種々の黄色系アゾ基を導入し, ついでテト ラクロルフタル酸無水物と縮合して得た多数のフタロン 系顔料の合成法とその顔料適性について述べる。

\section{2. 顔料の合成経路}

\section{1 中間体の合成}

中間体である 2-メチル-5-ベンツイミダゾールジアゾ ニウムクロライド（U），执よび 5-アセトアセチルアミ ノー2ーメチルベンッイミダゾール（VII）までの合成経路を 図-1 に示す。

まず, 0 ーフェニレンジアミンに塩酸の存在下酢酸を作

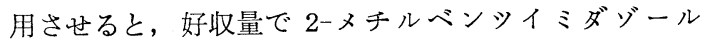
（III）が得られ, ついで混酸中, 室温でニトロ化すると 5-ニトロ-2-メチルベンツイミダท゙ール（N）が得られ る。このものは $p$-ニトローO-フェニレンジアミンに塩酸 の存在下酢酸を作用させても, 同様に好収量で得ること ができる。これを水中，鉄・塩酸で還元すると，5-アミ ノ-2-メチルベンシイミダジール（V）が容易に得られ る。このアミノ化合物のジアゾ化は, 常法にしたがっ て，希塩酸中亜硝酸ナトリウムを作用させることにより 行なわれる。一方，アミノ化合物（V) に水中でジケテ

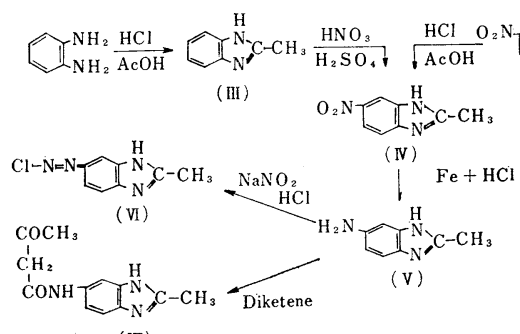

(VII)

Fig. 1. Synthetic processes of intermediates
ンを作用させると，好収量で 5-アセチルアミノ-2-メチ ルヘシンッイミダゾール（VI）が得られる。

\section{2 顔料 (I) の合成}

図-2 に示寸ように種々のジアゾ成分を，5-アセトア セチルアミノ-2-メチルベンッイミダゾール（VI）に酸性<smiles>CC(=O)C(NC(=O)C(Cl)Cl)c1ccc2nc(C)[nH]c2c1</smiles>

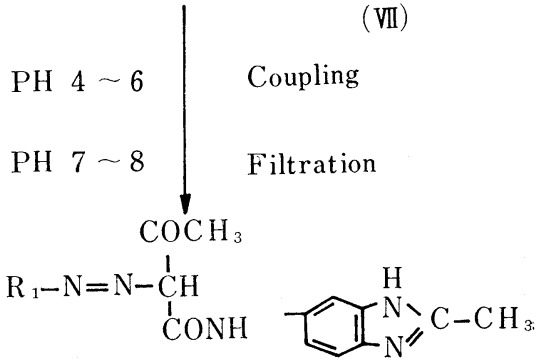

(VIII)<smiles>O=C1OC(=O)c2c(Cl)c(Cl)c(Cl)c(Cl)c21</smiles>

Pigments ( I )

Fig. 2. Synthetic processes of pigments ( I)

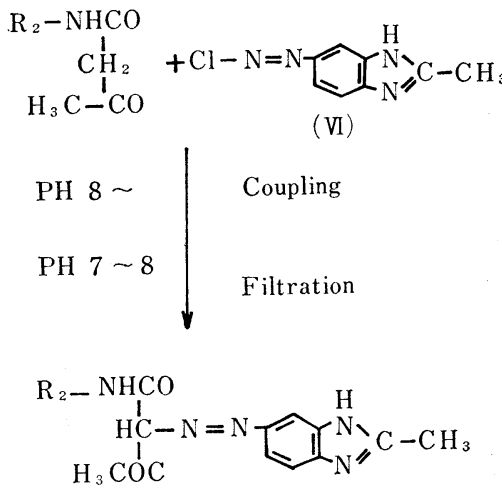

(IX)

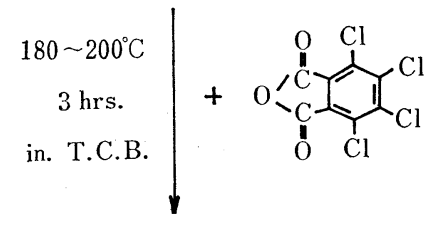

Pigments (II)

Fig. 3. Synthetic processes of pigments (II) 
カップリングすると多くのアゾ色素（VI）が得られ，つ いで高沸点溶剂中テトラクロルフタル酸無水物と縮合す ると目的とする顔料（I）が得られる。

\section{3 顔料 (II) の合成}

図-3 に示すようにジアゾ化合物 (U) を種々のアセト 酷酸アニライド類にアルカリカップリングすることによ り多くのアゾ色素 $(\mathbb{X})$ が得られ，ついで高沸点溶剤中 テトラクロルフタル酸無水物と縮合すると目的とする顔 料（II）が得られる。

これらの顔料（I），および（II）はいずれも新規化合 物である。

\section{3. 実験}

\subsection{5-アミノ-2-メチルベンツイミダゾール（V）の} 合成

3.1 .12 2-メチルベンッイミダゾール（III）

文献6)を参照して，oーフェニレンジアミン $108 \mathrm{~g}(1.0$ モル), 承酢酸 $90 \mathrm{~g}(1.5$ モル), 濃塩酸 $(37 \%) 200 \mathrm{~g}$ を 水 $3,000 \mathrm{~m} l$ 中, $90^{\circ} \mathrm{C}, 2$ 時間かきまぜる。冷却後アン モニア水で中和し, 析出した沈殿を沪別乾燥して, 目的 とする 2-メチルベンッイミダゾール（III） $123 \mathrm{~g}$ (粗収率 93\%) を得た。水から再結晶して無色針状晶（mp 174 $\sim 5^{\circ} \mathrm{C}$ ) を得た。 $\mathrm{mp} 176^{\circ} \mathrm{C}$ (文献值 ${ }^{6)}$ )

3.1 .25 5-ニトロ-2-メチルベンツイミダゾール (N) 文献7)を参照して，2-メチルベンッイミダゾール 132 g (1.0 モル)を, 発煙硝酸 $(d=1.52) 46 \mathrm{~m} l$ (1.1 モル) を濃硫酸 $(97 \%) 400 \mathrm{ml}$ に溶解した混酸中に，発熱に 注意しながら $30^{\circ} \mathrm{C}$ 以下で徐々に投入し, 同温度で 3 時 間かきまぜる。つぎにこの反応液を氷水 $3,000 \mathrm{ml}$ 中に 注入し, ついでアンモニア水で中和後, 沪過, 水洗, 乾 燥すると目的とする 5-ニトロ-2-メチルベンツイミダゾ 一ル (N) $168 \mathrm{~g}$ (粗収率 95\%) が得られる。水から再 結晶して無色針状晶 $\left(\mathrm{mp} \mathrm{218} \sim 9^{\circ} \mathrm{C}\right)$ を得た。 $\mathrm{mp} 219^{\circ} \mathrm{C}$ (文献値 ${ }^{7)}$ )

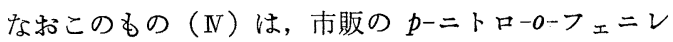
ンジアミン $\left(\mathrm{mp} \mathrm{201} \sim 204^{\circ} \mathrm{C}\right)$ を使用して 3.1 .1 と同様 な処理を行ならことによっても容易に，かつ好収率（粗 収率 97\%) で得ることができた。

$3.1 .35-$ 5ミノ-2-メチルベンッイミダゾール (V)

5-ニトロ-2-メチルベンッイミダジール（N） $70.9 \mathrm{~g}$ (0.4 モル) を水 $500 \mathrm{~m} l$ 中に分散けん濁し, 濃塩酸 (37 \%) $3 \mathrm{~g}$ を加えて $80^{\circ} \mathrm{C}$ に加熱後，鉄粉 $67 \mathrm{~g}$ (1.2 モル) を徐々に投入する。ついで $90 \sim 95^{\circ} \mathrm{C} て ゙ 4$ 時間かきまぜ た後, アンモニア水を少量加えて弱アルカリ性にし, 熱 時沪過する。沪液を減圧下に濃縮して液量を $200 \mathrm{~m} l$ 位
にした後, $5^{\circ} \mathrm{C}$ 以下で 48 時間放置する。析出した淡褐 色沈殿を沪別乾燥して, 目的とする 5-アミノー2-メチル ベンッイミダゾール（V) $40 \mathrm{~g}$ (粗収率 $68 \%$ ）を得た。 活性炭処理して無色釬状晶 $\left(\mathrm{mp} 53 \sim 54^{\circ} \mathrm{C}\right)$ を得た。

\subsection{5-アセトアセチルアミノー2-メチルベンツイミダ} ゾール（UI）の合成

5-アミノ-2-メチルベンッイミダゾール $147 \mathrm{~g}$ (1.0 モ ル）を $3 \%$ の䣫酸 $2,000 \mathrm{ml}$ に溶解し, $20^{\circ} \mathrm{C}$ でジヶテ ン $92.4 \mathrm{~g}$ (1.1 モル) を滴下し，同温度で 1 時間かきま ぜた後, 加熱して $80^{\circ} \mathrm{C} て ゙ 2$ 時間かきまぜる。冷却後ア ンモニア水で中和し， $5^{\circ} \mathrm{C}$ 以下で 48 時間放置する。析 出した無色沈殿を沪別し, 泠水で水洗後乾燥すると, 目 的とする 5-アセトアセチルアミノー2-メチルヘシンッイミ ダゾール $226 \mathrm{~g}$ (粗収率 $98 \%$ ) が得られる。水から再結 晶して無色針状晶 $\left(\mathrm{mp} 185^{\circ} \mathrm{C}\right.$ dec.) を得た。

\subsection{2-メチル-5-ベンツイミダゾールジアゾニウムク} ロライド (V)の合成

5-アミノ-2-メチルベンッイミダท゙ール $14.7 \mathrm{~g}(0.10$ モ ル）と濃塩酸 $(37 \%) 30 \mathrm{~g}$ を水 $100 \mathrm{ml}$ 中に溶解し, 亜 硝酸ナトリウム $7.2 \mathrm{~g}\left(0.105\right.$ モル) を $5^{\circ} \mathrm{C}$ 以下で投入し， 同温度で 1 時間かきまぜる。ついでスルファミン酸で過 剩の亚硝酸ナトリウムを分解する。この水溶液に活性炭 $5 \mathrm{~g}$ を加えて 5 分間かきまぜた後, 汇過すると褐色透明 な液となる。これは目的とする。2-メチル-5-ベンッイミ ダゾールジアジニウムクロライド（V）の水溶液である が, このものは単離することなく, 次のカップリング反 応に使用した。

\section{4 アゾ色素の合成}

3.4 .1 黄色アゾ色素 (VII) の合成

現在市販されているベース類は，きわめて多いが，今 回は無作為に次の 21 種類のベース $\left(\mathrm{R}_{1}-\mathrm{NH}_{2}\right)$ を使用し た。

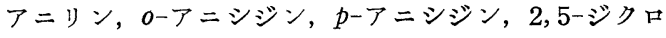

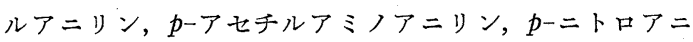

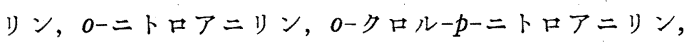

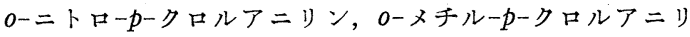
ン, 2-メチル-3-クロルアニリン, 2-メチル-5-クロルア ニリン， 0 -メトキシー - -ニトロアニリン， アントラニル 酸メチル，2，4,5-トリクロルアニリン，2-メトキシ-5メチル-4-ベンゾイルアミノアニリン，2-メトキシ-5-フ ェニルカルバモイルアニリン，2-メトキシ-5-カルバモ イルアニリン 2-クロル-5-カルバモイルアニリソ， $\alpha-$ アミノアントラキノン， 1-(3'-アミノ-4'-メチルヘンン゙ イルアミノ) -2, 5-ジメチルベンゼン。これらのベースは 市販品を特に精製することなくそのまま使用した。これ 
らのジアゾ化は，常法にしたがって，ベースに対して 3 モル比の塩酸中, 少過剩の亜硝酸ナトリウムを $5^{\circ} \mathrm{C}$ 以下で反応させた後，活性炭処理を行なった。また希 塩酸中でのジアジ化が困難なものについてはニトロシ ル硫酸法によった。一方，カップラーである 5-アセ トアセチルアミノ-2-メチルベンッイミダゾール（VII） は, 等モルの水酸化ナトリウム水溶液に溶解後, 希酢 酸で中和し，さらにベースに対して 2.5 モル比の酢酸 ナトリウムを加えて調製した。この中に上記ジアゾ化 合物の水溶液を徐々に $20^{\circ} \mathrm{C}$ 以下に保ちながら滴下し, 同温度で 1 時間かきまぜた。ジアジ化合物が無くなっ たことを確認後，アンモニア水を加えて $\mathrm{pH} 7$ 亿 し， $80^{\circ} \mathrm{C}$ まで加熱後 1 時間かきまぜ，ついで熱時沪 過した。水洗, 乾燥し目的とする黄色系アゾ色素( VIII) を，いずれも定量的な収率で得た。

\section{4 .2 黄色系アゾ色素 $(\mathrm{X})$ の合成}

現在黄色系カップラーとして知られている多数のア セト酢酸アニライド類のうち, 次の 8 種類を無作為に 選んで使用した。市販品については特に精製すること なく，そのまま使用した。それ以外について，相応す るアミノ化合物を適当な溶剤中ジヶテンを作用させて 合成し，その粗製品をとのまま使用した。

アセトアセチルアミノベンゼン，アセトアセチルア ミノーpーメトキシベンゼン，アセトアセチルアミノーpアセチルアミノベンゼン，1-アセトアセチルアミノー 2,5-ジメトキシ-4-クロルベンゼン，1-アセトアセチ ルアミノ-2,4-ジクロルベンゼン，1-アセトアセチル アミノ-2,4-ジメトキシベンゼン，1-アセトアセチル アミノ-2,4-ジメチルベンゼン，1-アセトアセチルア ミノナフタリン。

ベースは，3.3 で合成した 2-メチル-5-ベンツイミ ダゾールジアゾニウムクロライド（V）であるが，こ のものは酸性ないし中性では，カップリング反応が進 行しないのでアルカリカップリングを行なった。すな わらカップラーである上記アセト酢酸アニライド類を カップラーに対し 3.3 モル比の水酸化ナトリウム水溶 液に溶解後, ジアゾ化合物 $(\mathrm{V})$ の塩酸水溶液を $10^{\circ} \mathrm{C}$ 以下で滴下する。20 30 ${ }^{\circ} \mathrm{C} て ゙ 1$ 時間かきまぜた後, $80^{\circ} \mathrm{C}$ まで加熱しさらに 1 時間かきまぜる。熱時炉過 し, 水洗後乾燥すると, 目的とする黄色系アゾ色素 （X）がいずれも定量的な収率で得られた。

こうして得たアゾ色素 (III)，および（X) は精製す ることなく，そのまま以下の反応に使用した。

3.5 顔料 (I), および (II) の合成

黄色系アゾ色素 (UII)，または（X)とその黄色系ア
Table 1.

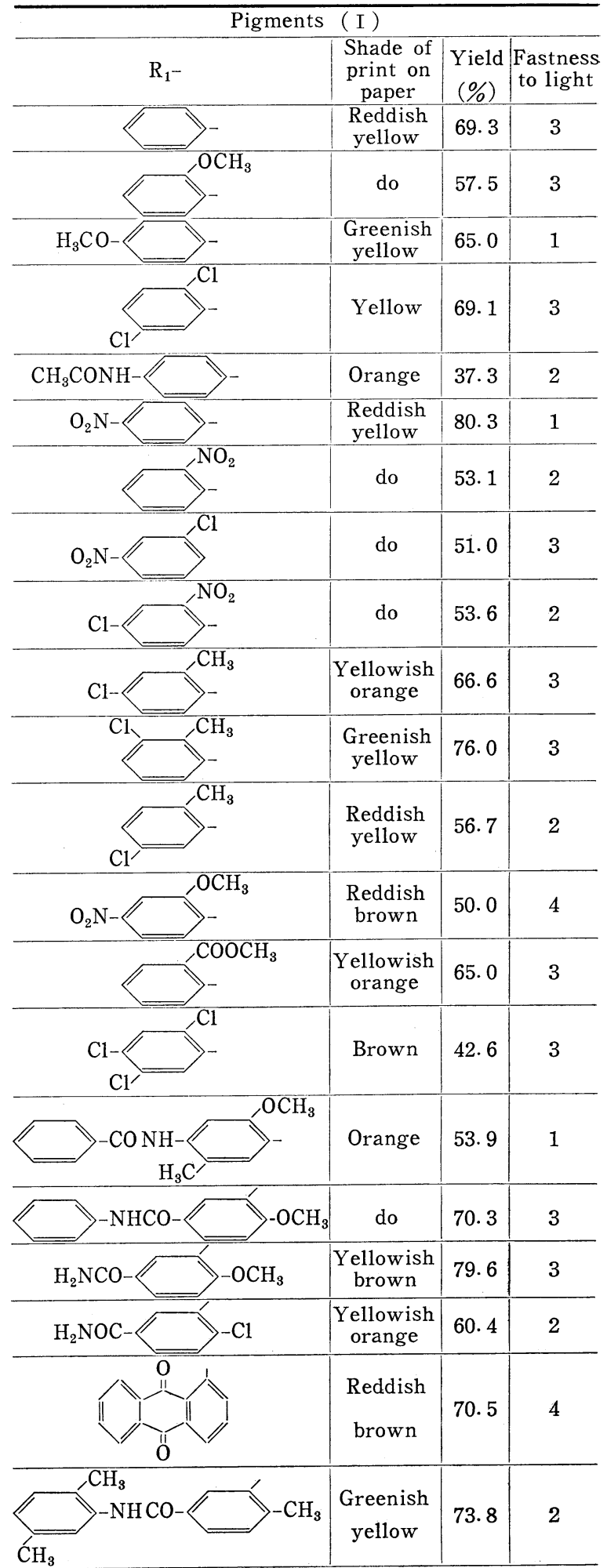


Table 2.

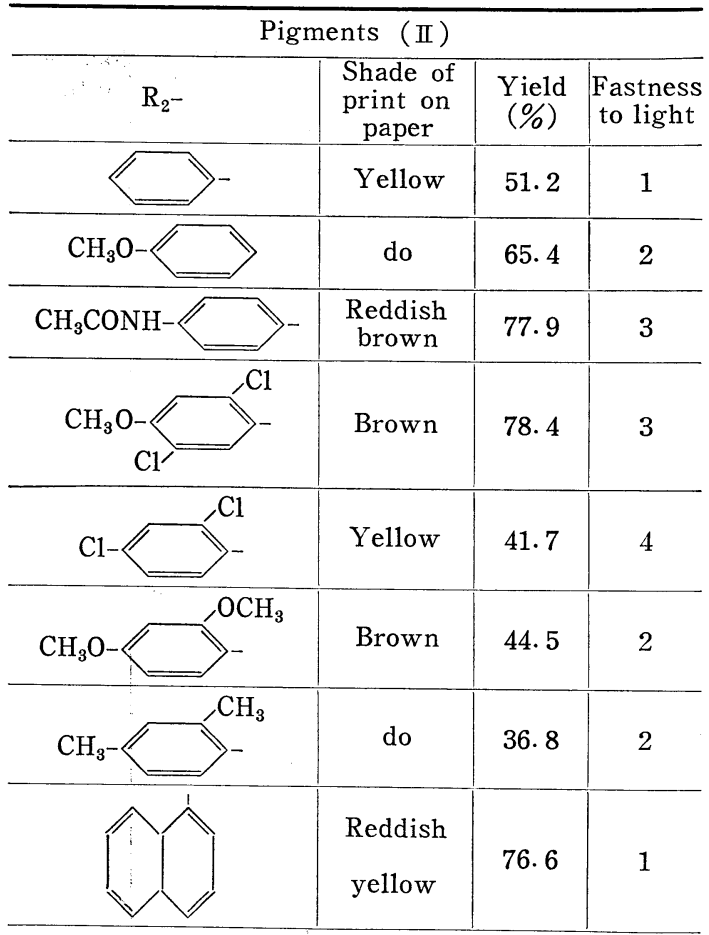

ゾ色素に対し 1.2 モル比のテトラクロルフタル酸無水物 を, 黄色系アゾ色素に対し約 20 倍重量のトリクロルベ ンゼン中発生する水を留去しつつ $180 \sim 200^{\circ} \mathrm{C}$ で 3 時間 かきまぜた後，析出した顔料を $80^{\circ} \mathrm{C}$ で熱時汇過する。 これをジメチルホルムアミド (DMF) で十分洗浄後, 同 様に約 20 倍重量の $\mathrm{DMF}$ 中に分散し, $120 \sim 130^{\circ} \mathrm{C}$ で 2 時間かきまぜた後, $80^{\circ} \mathrm{C}$ で熱時沪過し, メタノール， 熱水の順で洗浄後乾燥すると, 目的とする顔料（I）拉 よび（II）が得られる。こうして得た顔料の色相，黄色 系アゾ色素に対する対理論収率，および耐光性は，表1，および表-2 に示した。これらの顔料の融点は，いず れる $360^{\circ} \mathrm{C}$ 以上である。以下これらの顔料は，その適性 試験に際し，特にボールミリングその他の公知の顔料化 を行ならことなく使用した。

\section{6 顔料の耐光性試験}

顔料 $0.1 \mathrm{~g}$ ，チタンホワイト $\left(\mathrm{TiO}_{2}\right) 2.0 \mathrm{~g}$ を 4 号ワ ニス (大日本インキ製) $1.0 \mathrm{~g}$ ととるにフーバーマーラ 一で $100 \times 3$ 回練肉して顔料の淡色インキを作って展色 紙に展色し, STANDARD FADE METER (東洋理化工 業 (株) 型式 FA-1 型) で 100 時間暴露した。耐光性の 目安としては，グレースケール（5段階評価）によった。 すなわち暴露する前の色相と暴露後の色相の変退色の程 度を肉眼でグレースケールと比較し, 全く変退色してい
ないものを 5 , わずかに変退色しているものを 4 , 以下 $3 ， 2 ， 1$ の 5 段階の評価を与えた。

\section{7 溶剤性試験}

溶剤性試験としては，今回は実用上の試験として，メ ラミンアルキド樹脂塗料におけるブリード試験を行な った。すなおち，顔料 12 部，メラミンアルキド樹脂 188 部（大日本インキ製）を 3 本テストロールにて 6 回 練肉分散して色エナメルとし, 溶剤（キシレン：ブタ） ール=7:3）で希釈し，塗装板にスプレー塗装後， 120 ${ }^{\circ} \mathrm{C}$ で 30 分焼付ける。こうして顔料の濃色塗装板を得 る。一方, 白エナメルを別途調製する。すなわち, チ タンホワイト 30 部, メラミンアルキド樹脂 70 部を 3 本 テストロールにて $4 \sim 5$ 回練肉分散して白エナメルと し, 溶剤で希釈して上記濃色塗装板にオーバーコートし て, $160^{\circ} \mathrm{C} て ゙ 30$ 分焼付けてブリード状態を見る。耐ブ リード性の悪い顔料の場合は,この白色塗膜が着色する。

\section{8 耐薬品性試験}

耐薬品性試験としては, 今回は上記濃色塗装板につい て行なった。すなわち, 耐酸性試験としては, 濃色塗板 装を $10 \%$ 硫酸中に $25^{\circ} \mathrm{C}$ で 24 時間浸せきし, また耐ア ルカリ性試験としては, 10\% 水酸化ナトリウム水溶液 中に $25^{\circ} \mathrm{C}$ で 24 時間浸せきし, 各々その着色塗膜の変 退色の度合を 5 段階で評価し，5は全く変退色しないも の，4 はわずかに変退色したもの，以下 $3 ， 2 ， 1$ で 1 は完全に変退色したものを示す。

\section{9 耐熱性試験}

耐熱性試験としては，ポリエチレンで行なった。すな わち顔料とステアリン酸西鉊を $1: 4$ の割合でブレンド してドライカラーを作り，ついでこのドライカラー 0.5 部をポリエチレン 100 部にブレンドする。これは顔料分 $0.1 \%$ の濃色試料となる。耐熱性試験の条件としては, 温度は $230^{\circ} \mathrm{C}$ および $250^{\circ} \mathrm{C}$, 帯留時間は 0 分, 5 分, 10 分で射出成型した。こうして得たポリエチレンの着色プ レートについて各々の変退色の度合を調べた。これらの 評価も，耐薬品性試験と同椂に 5 段階で判定した。

\section{4. 結果と考察}

顔料（I）抽よび（II）の色相, 対応する黄色系アゾ 色素に対する対理論収率, および耐光性試験結果を, そ れぞれ表-1，および表-2 に示す。

色相としては, 顔料（Ｉ）の場合には青味黄色から橙 色および褐色まで, 顔料（II）の場合には, 黄色から主 として褐色まで広範囲にわたっている。周知のように顔 料は, 構造が同一であってもその結晶の大きさや結晶形 により，その色相がかなり異なることが多いので，表-1 


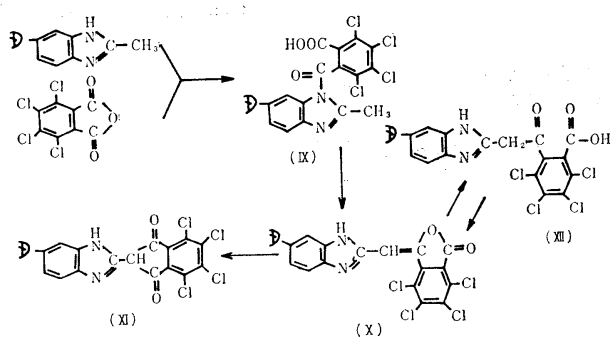

Fig. 4. Reaction mechanisms

および表-2 に示したよらな顔料の置換基の差による色 相への系統的な影響を見つけることは困難である。ただ これらの顔料の色相は, いずれもアゾ基の影響をもっと も多く受けているので，この中にも多くの例外はあるが 一般のアゾ顔料と同様に電子供与性基の存在する場合に は, 深色に移動する傾向がある。

顔料の収率については，大きなばら方がみられるが， これはそれぞれのアゾ色素の活性メチル基の反応性に差 があるためと思われる。従って, 実際の工業化に際して は，それぞれについて最適な合成条件を見いだす必要が ある。

これらのアゾ色素とテトラクロルフタル酸無水物との 反応機構については，特には検討を行なっていないが， 図-4に示すようにDが水素原子の場合には，すでに筆 者らの研究室で詳細に調べられている。参考までに簡単 に説明を加える。2-メチルベンッイミダゾール（III）へ のテトラクロルフタル酸無水物の攻撃は, 従来のキナル ジンの場合のように活性メチル基へではなく, 二級アミ ンに対するアシル化反応である。このアシル化物 ( $\mathrm{X})$ は無色の化合物で安定に単離することができる。Dが水 素原子ではなくアゾ基である場合にも同様な反応が起き るが，その場合，置換基Dの位置が 5 位か， 6 位か，あ るいはその混合物であるのか不明である。さて, 次にこ のアシル化物（X）は，加熱すると転位と脱水閉環を伴 なって蛍光を有するフタリド化合物（X）となる。これ は, さらに高温に加熱するか, 酸あるいは塩基触媒によ り転位して目的とするフタロン顔料 (XI) となる。一方, 上記したフタリド化合物（X）は，容易に加水分解して 無色の化合物（XII）になる。これはらょらどテトラクロ ルフタル酸無水物が，（III）の活性メチル基に付加反応し た形のものである。そしてこれは無水酢酸とともに加熱 すると, 脱水閉環してもとの淡黄色蛍光物質であるフタ リド化合物 $(\mathrm{X})$ になる。以上の反応機構は，Dがアゾ 色素の場合にもあてはまるものと思われる。

次に耐光性試験結果については, 表-1 および表-2 に 示したように全く変退色しない5の判定のものはなかっ
た。一部 4 の評価のものもあるが一般には変退色が大き く，耐光性は良くなかった。これはアゾ基の影響が大き いためと考えられる。

耐溶剤性試験の一環として行なったメラミンアルキ ド樹脂塗料による $160^{\circ} \mathrm{C} 30$ 分のブリード試験の結果, すべての顔料が，全くブリードしなかった。したがって この一連の顔料は耐溶剤性がきわめて良好であると言え る。

耐薬品性試験について，10\% 硫酸および 10\% 水酸化 ナトリウム水溶液中への浸せきテストによる変退色の度 合は，いずれも 5 段階評価で $4 \sim 5$ であり実用上全く問 題にならず耐薬品性についてもきわめて良好であった。

耐熱性試験については，ポリエチレンの成型温度およ び滞留時間による着色プレートの変退色の度合を調べた が，いずれの顔料に拈いても 4 〜 5 判定であり, 耐熱 性についてもかなり良好であると言える。

な铲顔料としての条件のうち，かかすことのできない ものに着色力がある。今回合成した顔料については，20 倍重量のチタンホワイトでうすめて得たインキの展色試 料により, 従来の顔料と比較検討した。その結果, 特に 顔料化処理を行なっていないにもかかわらず，ジスアげ 顔料に匹敵する着色力を有するものが半数近くに達し た。その他のものでも市販されている黄色系高級顔料に 匹敵し，一般に，この一連の顔料は着色力がかなり大で あると言える。

\section{5. 結論}

今回報告した顔料（Ｉ）および（II）の色相は，青味 黄色〜橙色〜褐色まで広範团にわたったが，その耐光性 は，アゾ基の影響を大きく受け，一部を除いて良くなか った。一方このアゾ基を導入することにより着色力の きわめて大きな顔料が多数得られた。また耐溶風性, 而 薬品性，耐熱性についてはイミダゾール・フタロン骨格 の影響を大きく受け，いずれすきわめて良好であった。 したがってこれらの顔料のうちいくつかは，その用途に よっては，十分な実用上の利用価値があると思われる。

このよらなフタロン系顔料は, 今後とも研究が進めら れ，実際に上市されるものも増してくるものと思われ る。（1975年 4 月 日本化学会第 32 春季年会発表）

$$
\text { 文献 }
$$

1) 大日本インキ, 特公昭 48-3523

2) E. Jacobsen, Rermer : Ber., 16, 513 (1883)

3） 三菱化成，特公昭 48-30736

4) BASF，特公昭 48-102130

5) BASF，特公昭 47-3476

6) Montague A. Phillips : J. Chem.Soc., 2393(1928

7) O. Fisher: Ber., 36, 3970 (1903) 